\title{
INTRODUCTION TO DEFENSE ACQUISITION MANAGEMENT
}

\section{NINTH EDITION}

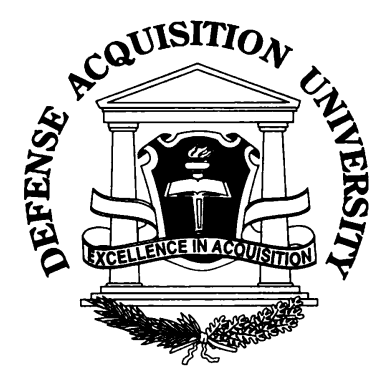

\section{SEPTEMBER 2009}

\author{
PUBLISHED BY THE
}

DEFENSE ACQUISITION UNIVERSITY PRESS FORT BELVOIR, VIRGINIA 